\title{
EFFECTS OF SOME SOIL CONDITIONERS ON YIELD AND UPTAKE OF SOME MACRO- MICRONUTRIENTS BY MAIZE SUCCEEDED BY WHEAT PLANTS GROWN ON TWO NEWLY RECLAIMED SOILS IN EGYPT
}

Habib, F. M. ${ }^{*}$; A. H. Abd El-Hameed ${ }^{\star}$; M. S. Awaad ${ }^{\star *}$ and T. H. M. A. Deshesh**

* Faculty of Agriculture, Banha University

** Soils, Water and Environ. Res. Inst., Agric. Res. Center (ARC), Giza, Egypt.

\begin{abstract}
A field experiment was conducted on a calcareous clay loamy and non calcareous sandy soils at Atfeh region, Giza Governorate to evaluate the effect of different organic materials, i.e., vinasse, (A1), farmyard manure $F Y M$, (A2) town refuse compost (A3) and farm refuse compost (A4) applied at two rates of 5 and 10 ton fed. ${ }^{-1}$ just before maize planting on its shoots, grain and biological yields as well as uptake values of $\mathrm{N}, \mathrm{P}, \mathrm{K}, \mathrm{Fe}, \mathrm{Cu}, \mathrm{Mn}$ and $\mathrm{Zn}$ by its shoot and grains. Wheat was grown in the same plots without any further application of the aforementioned organic materials to study their residual effect on straw, grain and biological yields as well as, uptake values of the abovementioned nutrients by straw and grain of wheat plant. Results showed that application of the used organic manures to both the studied soils increased values of the shoot, grain and biological yield $\mathrm{s}$ of maize compared to the control treatment. Also, values of $\mathrm{N}, \mathrm{P}, \mathrm{K}, \mathrm{Fe}, \mathrm{Cu}, \mathrm{Mn}$ and $\mathrm{Zn}$ uptake by shoot and grain of maize plant increased as compared to the corresponding ones the control treatment. Also, increases in the uptake values. More pronounced at the higher rate of the applied organic materials. The highest values of the above mentioned parameters were achieved awing to vinasse (A1) application to the investigated soils. Similarly, values of shoots, grain and biological yields and total uptake of $\mathrm{N}, \mathrm{P}, \mathrm{K}, \mathrm{Fe}, \mathrm{Cu}, \mathrm{Mn}$ and $\mathrm{Zn}$ by straw and grain of wheat plant achieved higher values than the corresponding ones of the control treatment due to the residual effect of the previously applied soil conditioners (organic material). The results also showed that the increases were more pronounced due to the higher rate of these conditioners. The highest values of straw, grains and biological yields of wheat grown on both calcareous clay loamy and non calcareous sandy soils were recorded for treatments previously FYM. The findings imply that the highest values of $\mathrm{N}$ and $\mathrm{P}$-uptake by wheat plant were obtained due to residual effect of FYM in both the calcareous clay loamy and non calcareous sandy soils. However, the highest values of K-uptake by wheat plant were obtained due to application of vinasse in both the calcareous clay loamy and non calcareous sandy soils. On the other hand, the residual effect of farm refuse compost and FYM recorded the highest values of $\mathrm{Fe}, \mathrm{Cu}, \mathrm{Mn}$ and $\mathrm{Zn}$ uptake by straw of wheat plants grown on both the studied soils. Contrary to that the residual effect of FYM and farm refuse compost recorded the highest values of $\mathrm{Fe}, \mathrm{Cu}, \mathrm{Mn}$ and $\mathrm{Zn}$ uptake by grain of wheat plant grown on both the studied soils, respectively.

Keywords: Soil, vinasse, farmyard manure, town refuse compost and farm refuse compost
\end{abstract}


Habib, F. M. et al.

\section{INTRODUCTION}

The land mass area of the country is fairly large, as it extends over one million square kilometers. However, the actively cultivated area is only 3.6 million hectares, located mostly in the Nile Valley Delta. Recently, it became necessary to look for soils suitable for cultivation among the desert soils. This would be an aimed target to come over the gap between food production and the increased population. These soils in valves both sand and calcareous clay loamy ones which are poor in mineral and organic colloids, and subsequently they are low in natural fertility i.e. suffer shortage in both macro-and micronutrients beside of their micronutrients beside of their low water retention. The primary sources of soil organic matter are plant and animal residues. Soil organic matter is important for maintaining good soil structure, which enhances the movement of air and water in soil. Organic matter also plays an important role in nutrient recycling. It has been shown that addition of organic materials caused improve soil properties such as water-holding capacity, hydraulic conductivity, bulk density (Carter and Stewart, 1996; Zebarth et al., 1999; Franzluebbers, 2002). and at the same time caused increases in plant dry matter yield and its uptake of the macro and micro nutrient elements (Abdas et al., 2009). The present work aims at studying the effect of different organic manures (soil conditioners) on the yields of maize and wheat successively cultivated on calcareous clay loamy and non calcareous sandy one. Also, values of some macro-and micronutrients content in the plants were a matter of concern in the current work.

\section{MATERIALS AND METHODS}

\section{Study area}

The present study was carried out through a field experiments conducted in two different soils i.e. a non calcareous sandy soil and calcareous clay loamy one of private farms at Atfeeh, Giza, Governorate south Cairo. Some chemical and physical properties of the investigated soils were determined just before growing maize in summer season and before application of the different used organic materials (soil conditioners) according to the standard methods and obtained results are listed in Table 1.

Table 1: Same physical and chemical properties of the investigated soils.

\begin{tabular}{|c|c|c|c|c|c|c|c|}
\hline \multirow[b]{2}{*}{ Soil } & \multicolumn{3}{|c|}{$\begin{array}{l}\text { Particle size } \\
\text { distribution }\end{array}$} & \multirow{2}{*}{$\begin{array}{c}\text { Organic } \\
\text { matter } \\
\%\end{array}$} & \multirow{2}{*}{$\begin{array}{c}\mathrm{CaCO}_{3} \\
(\%)\end{array}$} & \multirow[b]{2}{*}{ pH } & \multirow{2}{*}{$\begin{array}{c}E C \\
d S ~ m^{-1}\end{array}$} \\
\hline & \begin{tabular}{|c|} 
Clay \\
$\%$
\end{tabular} & $\begin{array}{l}\text { Silt } \\
\%\end{array}$ & $\begin{array}{c}\text { Sand } \\
\%\end{array}$ & & & & \\
\hline The calcareous clay loamy & 21.40 & 23.50 & 55.10 & 0.46 & 34.00 & 8.01 & 4.20 \\
\hline The non calcareous sandy & 10.12 & 15.60 & 74.28 & 0.19 & 6.75 & 7.65 & 2.55 \\
\hline
\end{tabular}


Preparation of the organic materials or manures (soil conditioners) used in the experimental work:

Three sources of common traditional organic manures: FYM, farm refuse compost and town refuse compost besides of an untraditional one i. e. vinasse were used in this experiment. Preparation of these materials were conducted as described previously Habib et al., (2009)

The experimental work.

The used soil conditioners (vinasse, FYM, town refuse compost and farm refuse compost) were applied at rates of 5 and 10 ton fad $^{-1}$. Soil conditioners were mixed thoroughly with the top $30 \mathrm{~cm}$ surface layer of each plot. Some characteristics of the studied conditioners are presented in Table2.

Maize (Zea mays, single cross 10) was planted in the summer season of 2007, in plots the area of each is $10.5 \mathrm{~m}^{2}$. The experiment was conducted in a randomized complete block design with three replications.

All plots, received the NPK fertilizers at recommended doses for maize crop before cultivation where $\mathrm{P}$ and $\mathrm{K}$ were applied at rates of $15 \mathrm{~kg}$ $\mathrm{fed}^{-1}$ and $24 \mathrm{~kg} \mathrm{fed}^{-1}$ as superphosphate $\left(15 \% \mathrm{P}_{2} \mathrm{O}_{5}\right)$ and potassium sulphate $\left(48 \% \mathrm{~K}_{2} \mathrm{O}\right)$, respectively. Nitrogen was applied at a rate of $120 \mathrm{~kg} \mathrm{~N}^{-1} \mathrm{fed}^{-1}$ as ammonium nitrate $(33.5 \% \mathrm{~N})$ at three equal doses 15,45 and 60 days after sowing. Wheat (Triticum aestivum L., Sakha 69) was sown after maize harvesting, as a winter crop on 15 November 2007 and harvested on $5^{\text {th }}$ of May 2008, and the recommended doses of N, P and K were added to each plot which did not receive further organic materials.

At harvesting time, shoot or straw, grain, and total biological yields of each of maize and wheat were recorded. The nutrient contents of $\mathrm{N}, \mathrm{P}, \mathrm{K}, \mathrm{Fe}$, $\mathrm{Cu}, \mathrm{Mn}$ and $\mathrm{Zn}$ were determined in dry shoot or straw and grains for both maize and wheat according to Black et al. (1965).

Table 2: Some physical and chemical properties of the vinasse, farmyard manure, town refuse compost and farm refuse compost used in the experimental work.

\begin{tabular}{|l|c|c|c|c|}
\hline \multicolumn{1}{|c|}{ Parameter } & Vinasse & FYM & $\begin{array}{c}\text { Town refuse } \\
\text { compost }\end{array}$ & $\begin{array}{c}\text { Farm-refuse } \\
\text { compost }\end{array}$ \\
\hline Organic matter \% & 75.00 & 68.70 & 18.91 & 72.31 \\
\hline pH & 4.02 & 7.61 & 7.40 & 8.20 \\
\hline Total N \% & 1.08 & 1.43 & 1.03 & 1.33 \\
\hline Total P \% & 0.55 & 0.81 & 0.61 & 0.70 \\
\hline Total K \% & 0.41 & 0.71 & 0.21 & 0.60 \\
\hline C/N ratio & $15.70: 1$ & $13.20: 1$ & $16.60: 1$ & $14.72: 1$ \\
\hline Available Fe $\mathbf{~ m g ~ / ~ k g ~}$ & 944 & 600 & 143 & 50.00 \\
\hline Available Zn $\mathbf{~ m g ~ / k g ~}$ & 8.001 & 100 & 28.00 & 26.00 \\
\hline Available Mn $\mathbf{~ g ~ / ~ k g ~}$ & 6.50 & 50.32 & 25.00 & 28.00 \\
\hline Available Cu $\mathbf{~ g ~ / ~ k g ~}$ & 38.00 & 18.00 & 60.00 & 10.00 \\
\hline
\end{tabular}

$\mathrm{pH}$ at (1: $2.5 \mathrm{w} / \mathrm{v}$ organic amendment : water suspension) 


\section{Statistical analysis}

Data were analyzed by the methods described by Snedecor and Cochran (1982).

\section{RESULTS AND DISCUSSION}

Effect of the used organic materials (soil conditioners) on shoot, grain and biological yields of plants grown on both the investigated soils.

Data presented in Table 3 show effect of the used organic manures (soil conditioners) i.e. vinasse (A1), FYM (A2), town refuse compost (A3) and farm refuse compost (A4) on shoot, grain and biological yields for maize planted in the investigated soils. Shoots, grains and biological yields were increased as compared with the control treatments owing to application of the aforementioned organic materials. The relative increases shoots, grains and biological yield were, $(96.08,41.57,22.35$ and $76.69 \%),(81.88,42.43,24.54$ and $45.87 \%)$ and $(91.83,41.83,23.01$ and $66.76 \%)$ owing to the treatments $\mathrm{A} 1, \mathrm{~A} 2, \mathrm{~A} 3$ and $\mathrm{A} 4$, respectively in the calcareous clay loamy soil. The corresponding values in the non calcareous sandy soil were, $(105.97,76.31$, 20.52 and 79.85$),(32.50,30.63,12.50$ and $20.63 \%)$ and $(78.50,59.23,17.52$ and $57.71 \%$ ) at the same respective order.

Table 3: Effect of the used organic materials (soil conditioners) on dry shoot, grain and biological yields maize (ton fed..$^{-1}$ ) during plants grown on both the investigated soils.

\begin{tabular}{|c|c|c|c|c|c|c|c|c|c|c|c|}
\hline \multirow[t]{2}{*}{ item } & \multirow[t]{2}{*}{ Rate } & \multicolumn{5}{|c|}{ The calcareous clay loamy soil } & \multicolumn{5}{|c|}{ The non calcareous sandy soil } \\
\hline & & $A_{1}$ & $A_{2}$ & $\mathbf{A}_{3}$ & $\mathbf{A}_{4}$ & $\mathbf{M}$ & $\overline{A_{1}}$ & $A_{2}$ & $A_{3}$ & $\mathbf{A}_{4}$ & M \\
\hline \multirow{4}{*}{$\begin{array}{l}\text { Shoots } \\
\text { (ton fed.-1) }\end{array}$} & non & \multicolumn{5}{|c|}{5.10} & \multicolumn{5}{|c|}{2.68} \\
\hline & $\mathbf{R}_{1}$ & 9.00 & 5.30 & 5.28 & 7.82 & 6.85 & 4.38 & 4.16 & 2.49 & 4.14 & 3.79 \\
\hline & $\mathbf{R}_{\mathbf{2}}$ & 11.00 & 9.14 & 7.20 & 10.10 & 9.36 & 6.66 & 5.29 & 3.97 & 5.50 & 5.36 \\
\hline & mean & 10.00 & 7.22 & 6.24 & 8.96 & 8.11 & 5.52 & 4.73 & 3.23 & 4.82 & 4.57 \\
\hline \multirow{4}{*}{$\begin{array}{l}\text { grain } \\
\text { (ton fed.-1) }\end{array}$} & non & \multicolumn{5}{|c|}{2.18} & \multicolumn{5}{|c|}{1.60} \\
\hline & $\mathbf{R}_{1}$ & 3.81 & 2.49 & 2.46 & 2.92 & 2.92 & 1.98 & 1.96 & 1.68 & 1.84 & 1.87 \\
\hline & $\mathbf{R}_{\mathbf{2}}$ & 4.12 & 3.72 & 2.97 & 3.44 & 3.56 & 2.26 & 2.22 & 1.92 & 2.02 & 2.11 \\
\hline & mean & 3.97 & 3.11 & 2.72 & 3.18 & 3.24 & 2.12 & 2.09 & 1.80 & 1.93 & 1.99 \\
\hline \multirow{4}{*}{$\begin{array}{l}\text { biological } \\
\text { yield } \\
\text { (ton fed.-1) }\end{array}$} & non & \multicolumn{5}{|c|}{7.28} & \multicolumn{5}{|c|}{4.28} \\
\hline & $\mathbf{R}_{1}$ & 12.81 & 7.79 & 7.74 & 10.74 & 9.77 & 6.36 & 6.12 & 4.17 & 5.98 & 5.66 \\
\hline & $\mathbf{R}_{\mathbf{2}}$ & 15.12 & 12.86 & 10.17 & 13.54 & 12.92 & 8.92 & 7.51 & 5.89 & 7.52 & 7.46 \\
\hline & mean & 13.97 & 10.33 & 8.96 & 12.14 & 11.35 & 7.64 & 6.82 & 5.03 & 6.75 & 6.56 \\
\hline \multirow[t]{8}{*}{ LSD at 0.05} & & Shoots & Seeds & total & yield & \\
\hline & $S$ & 0.66 & 0.34 & 0.62 & \multirow{7}{*}{ 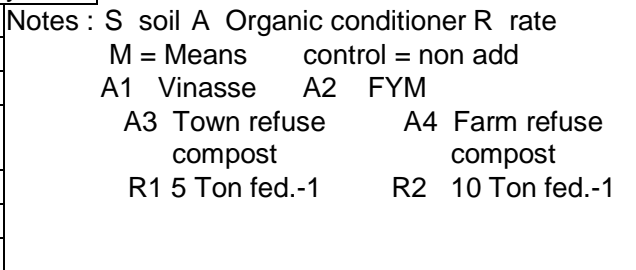 } & & & & & & \\
\hline & A & 0.93 & 0.47 & 0.87 & & & & & & & \\
\hline & $\mathbf{R}$ & 0.66 & 0.34 & 0.62 & & & & & & & \\
\hline & SA & 1.32 & 0.67 & 1.23 & & & & & & & \\
\hline & SR & ns & $\mathrm{ns}$ & $\begin{array}{l}0.78 \\
\end{array}$ & & & & & & & \\
\hline & AR & $\mathrm{ns}$ & $\mathrm{ns}$ & $\mathrm{ns}$ & & & & & & & \\
\hline & SAR & ns & ns & $\begin{array}{l}1.74 \\
\end{array}$ & & & & & & & \\
\hline
\end{tabular}

The increases in maize yields due to application of the different organic manures may be ascribed to the persistent effect of soil conditioners on soil properties relative to the plant growth on one side and the nutritional 
supply upon decomposition of these organic materials on the other hand. These results stand in well agreement with those of Judith et al. (2009) who concluded that the increase of maize yield in manured plots was attributed to the manure-derived nutrients and improved soil properties. Also, Sardoui et al. (2003) elucidated that addition of manure to non calcareous sandy soils could improve soil productivity and increase maize yield. It is worthy to note that vinasse treatment $(A 1)$ resulted in the highest values of shoots, grains and biological yields of maize plants grown on both the studied calcareous clay loamy and non calcareous sandy soils as compared to the other used organic manures.

Residual effect of the used organic materials (soil conditioners) on shoot, grain and biological yields of the wheat plants grown on both the investigated soils.

Data in Table 4 reveal that residual effect of the used organic manures i.e. vinasse (A1), FYM (A2), town refuse compost (A3) and farm refuse compost (A4) caused a significant increases in straw, grains and biological yields of wheat plants as compared with those attained due to the control treatment in both the investigated soils. The relative increases of straw, grains and biological yields of wheat due to application of the used manures were $(32.57,94.41,61.18$ and $92.11 \%),(40.21,90.72,57.22$ and $78.35 \%$ ) and (35.54, 92.97, 59.64 and $86.75 \%)$ for A1, A2, A3 and A4, respectively in the calcareous clay loamy soil.

Table 4: Residual effect of the used organic materials (soil conditioners) on dry straw, grain and biological yields of the wheat (ton fed. ${ }^{1}$ ) plant grown on the investigated soils.

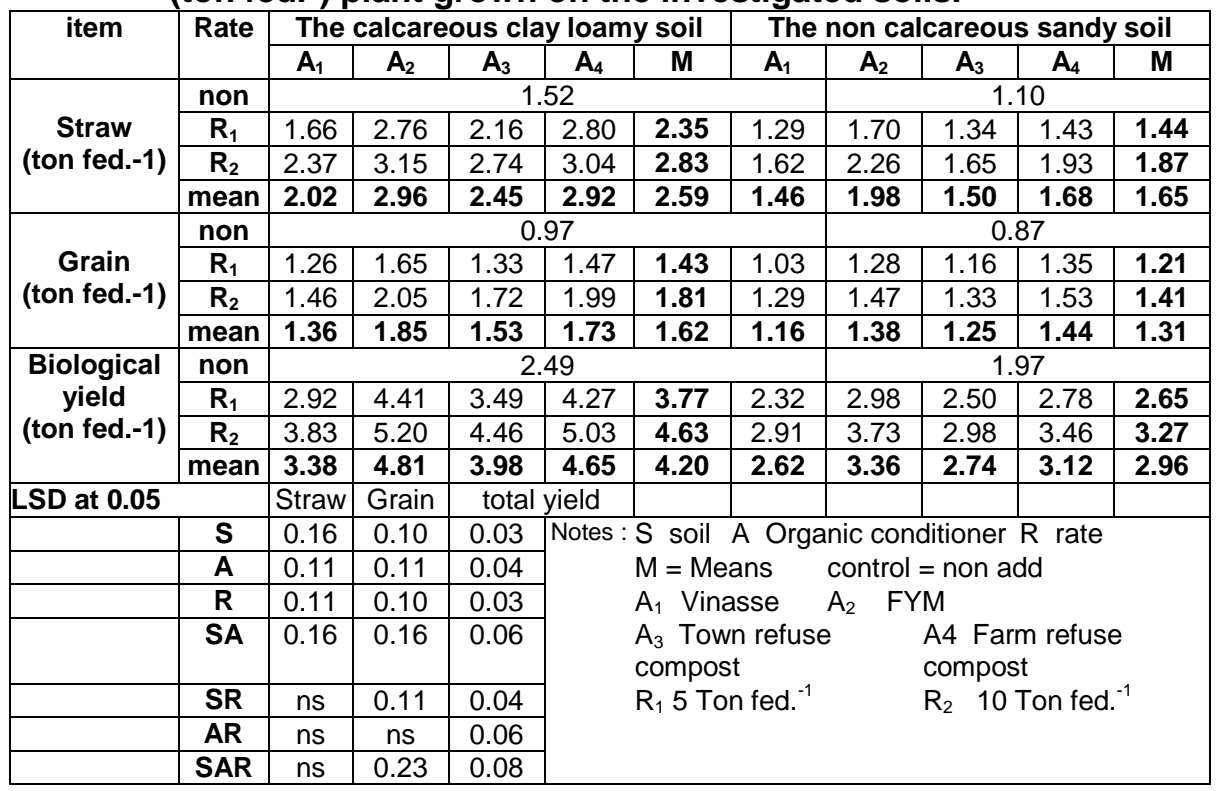


The corresponding values in the non calcareous sandy soil were, (32.27, $80.00,35.91$ and $56.52 \%)$, (33.33, 58.05, 43.10 and $65.52 \%)$ and $(32.74$, $70.30,39.09$ and $58.38 \%$ ) at the same respective order.

It is interesting to note that the highest values of the relative increases in straw, grains and biological yields of wheat grown on both the calcareous clay loamy and non calcareous sandy soils were recorded for the plots received farm yard manure (A2). These results may be due to FYM contains amounts of the plant nutrients e.i. N, P, K, Fe, Cu, Mn and Zn. Also, decomposition of the FYM might be slow and hence its use by the microorganisms is supposed to take a longer time, which is also necessary for long-term maintenance of the soil structure and fertility levels required for intensive crop production compared with other applied manures. This results agree with those of Bauer and Black (1994) who found that the low input of organic manures has favorable physical and chemical residual effect on soil and crop production. Heluf (2002) reported that there an increment of 0.47 ton $\mathrm{ha}^{-1}$ in grain yield of maize due to application of FYM during the first year over the treatment which did not receive FYM, whereas increasing FYM applications from $0-20$ ton ha $^{-1}$ increased wheat grain yield from 1.97 to 3.31 ton ha ${ }^{-1}$.

Effect of the used organic materials (soil conditioners) on macronutrients uptake by maize and wheat plants grown on both the investigated soils.

Nitrogen uptake

$\mathrm{N}$-uptake by maize plant

Data presented in Table 5 show the values of $\mathrm{N}$-uptake by maize plants progressively increased due to application of the used manures and the increases because more obvious increasing rates of application in both calcareous clay loamy and non calcareous sandy soils. When manures were applied as A1 (vinasse), A2 (FYM), A3 (town refuse compost) and A4 (farm refuse compost), values of $\mathrm{N}$-uptake by shoot and grain of maize plants grown on the calcareous clay loamy soil increased by about $215.10,77.98$, 46.82 and $96.58,87.70,63.76,43.03$ and $55.73 \%$ for shoots and grain, respectively. In the non calcareous sandy soil, these values reached 143.21 , $104.25,71.95$ and $118.14 \% \& 63.60,32.06,3.90$ and $20.96 \%$ for the above mentioned parameters, respectively.

The highest $\mathrm{N}$-uptake by maize plant was attained due to application of vinasse in both the calcareous clay loamy and non calcareous sandy soils. The achieved increases in $\mathrm{N}$ uptake values may be ascribed to the effect of the used manures on improving the penetration of the root and hence availability of plant nutrients. Moreover, the used manures are considered themselves as sources of $\mathrm{N}$ (see Table 2)

\section{$\mathrm{N}$-uptake by wheat plant}

The residual effects of the used organic manures on $\mathrm{N}$-uptake by wheat grown on the both calcareous clay loamy and non calcareous sandy soils are presented in Tables 6 . The nitrogen uptake by wheat plants was significantly increased and the increase was more pronounced with the high rate of the applied organic manures. The relative increases in $\mathrm{N}$-uptake by straw and grain of wheat plants due to residual effect of soil conditioners (A1, 
A2, A3 and A4) in the calcareous clay loamy soil were $(102.89,153.37,85.38$ and 113.50) and $(99.64,155.99,88.79$ and 150.60) for straw and grain, respectively. In the non calcareous sandy soil these values reached (46.92, $91.68,38.01$ and $66.00 \%)$ and $(113.34,160.37,108.31$ and $183.06 \%)$ for the above mentioned parameters, respectively. It is clear that nitrogen uptake by wheat plants was highest due to the residual effect of FYM compared with applied soil manures other in both the calcareous clay loamy and non calcareous sandy soils. These results may attributed to the decomposition of the used organic manures in both the studied soils which might have induced a slow release of nitrogen nutrient for the growing plants. Also, the ability of the applied organic manures to improvement the physical and chemical properties of the soil might provide more favorable comitias for plant growing and uptake of $\mathrm{N}$.

There results stand in well agreement with those of Krishna (2006) found that nutrient contents in the soil after the crop harvest were found higher where town farm refuse compost and FYM were applied. Carl and Peter (2005) stead that organic $\mathrm{N}$ released during the second and third cropping years after initial application will be $50 \%$ and $25 \%$, respectively, of that mineralized during the first cropping season.

Table 5: Effect of the used organic materials (soil conditioners) on $\mathrm{N}, \mathrm{P}$ and $\mathrm{K}$ uptake $\left(\mathrm{Kg} / \mathrm{fed}^{-1}\right)$ by shoots of maize grown on the investigated soils.

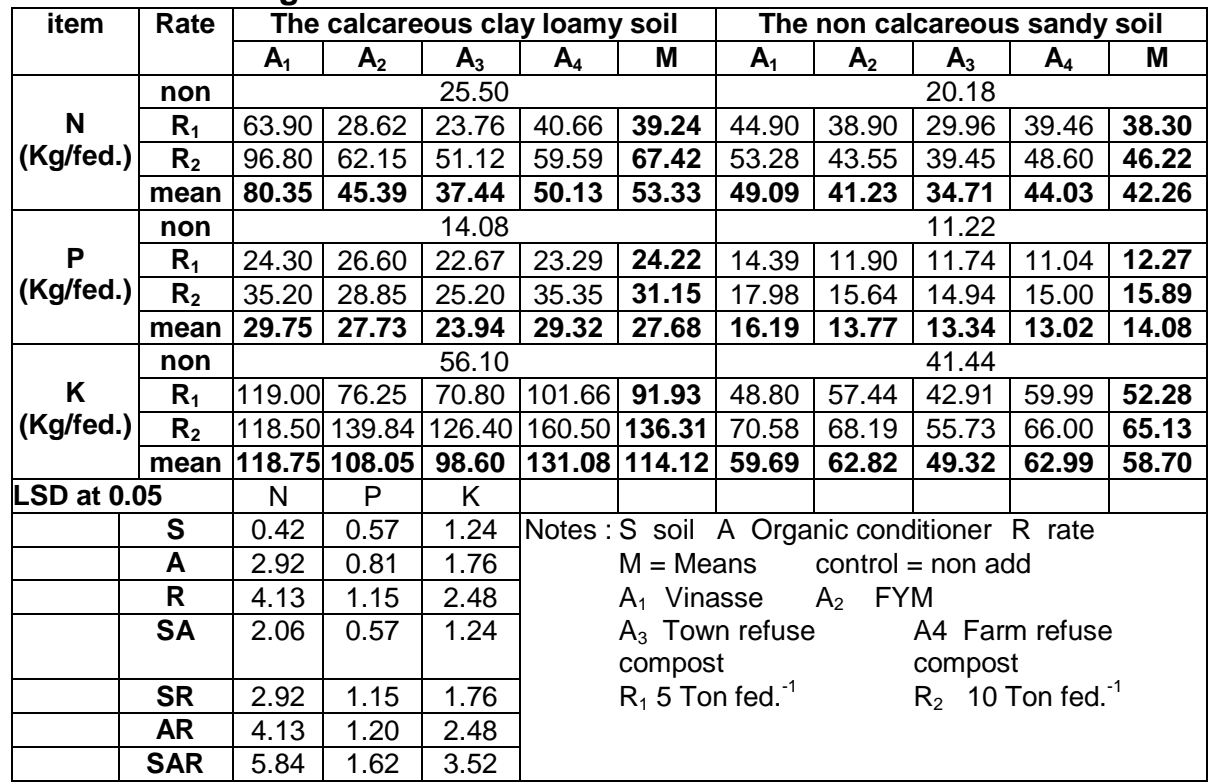


Habib, F. M. et al.

Table 6: Effect of the used organic materials (soil conditioners) on $\mathrm{N}, \mathrm{P}$ and $\mathrm{K}$ uptake $\left(\mathrm{Kg} / \mathrm{fed} .^{-1}\right)$ by straw of wheat plant grown on the investigated soils.

\begin{tabular}{|c|c|c|c|c|c|c|c|c|c|c|c|}
\hline \multirow[t]{2}{*}{ item } & \multirow[t]{2}{*}{ Rate } & \multicolumn{5}{|c|}{ The calcareous clay loamy soil } & \multicolumn{5}{|c|}{ The non calcareous sandy soil } \\
\hline & & $\mathbf{A}_{1}$ & $\mathbf{A}_{2}$ & $\mathbf{A}_{3}$ & $\mathbf{A}_{4}$ & $\mathbf{M}$ & $\mathbf{A}_{1}$ & $A_{2}$ & $\mathbf{A}_{3}$ & $\mathbf{A}_{4}$ & $\mathbf{M}$ \\
\hline \multirow{4}{*}{$\begin{array}{c}\mathrm{N} \\
(\mathrm{Kg} / \mathrm{fed} .)\end{array}$} & non & \multicolumn{5}{|c|}{9.80} & \multicolumn{5}{|c|}{5.81} \\
\hline & $\mathbf{R}_{1}$ & 18.61 & 20.70 & 13.61 & 19.32 & 18.06 & 5.93 & 9.35 & 6.90 & 7.58 & 7.44 \\
\hline & $\mathbf{R}_{\mathbf{2}}$ & 21.17 & 28.98 & 22.74 & 22.54 & 23.86 & 11.02 & 12.92 & 9.14 & 11.70 & 11.19 \\
\hline & mean & 19.89 & 24.84 & 18.18 & 20.93 & 20.96 & 8.48 & 11.13 & 8.02 & 9.64 & 9.32 \\
\hline \multirow{4}{*}{$\begin{array}{c}P \\
(\mathrm{Kg} / \mathrm{fed} .)\end{array}$} & $\mathbf{R}_{0}$ & \multicolumn{5}{|c|}{3.34} & \multicolumn{5}{|c|}{2.20} \\
\hline & $\mathbf{R}_{1}$ & 4.48 & 8.00 & 5.40 & 6.72 & 6.15 & 2.84 & 3.74 & 2.68 & 3.29 & 3.14 \\
\hline & $\mathbf{R}_{2}$ & 7.35 & 10.40 & 7.95 & 10.64 & 9.08 & 4.05 & 5.88 & 3.63 & 5.40 & 4.74 \\
\hline & mean & 5.84 & 9.16 & 6.62 & 8.61 & 7.53 & 3.42 & 4.75 & 3.14 & 4.28 & 3.88 \\
\hline \multirow{4}{*}{$\begin{array}{c}\mathrm{K} \\
(\mathrm{Kg} / \mathrm{fed} .)\end{array}$} & non & \multicolumn{5}{|c|}{16.72} & \multicolumn{5}{|c|}{9.90} \\
\hline & $\mathbf{R}_{1}$ & 28.72 & 46.92 & 32.40 & 49.00 & 39.26 & 20.64 & 25.50 & 16.75 & 21.88 & 21.19 \\
\hline & $\mathbf{R}_{2}$ & 43.85 & 54.50 & 43.84 & 54.72 & 49.23 & 26.24 & 37.74 & 23.10 & 32.42 & 29.88 \\
\hline & mean & 36.07 & 50.68 & 37.98 & 51.83 & 44.14 & 23.43 & 31.38 & 19.81 & 26.96 & 25.30 \\
\hline \multicolumn{2}{|c|}{ LSD at 0.05} & $\mathrm{~N}$ & $\mathrm{P}$ & $\mathrm{K}$ & \multirow{8}{*}{ Notes } & \multirow{8}{*}{$\begin{array}{l}\mathrm{M}=\mathrm{Me} \\
\mathrm{A}_{1} \mathrm{Vina} \\
\mathrm{A}_{3} \text { Tow } \\
\text { compos } \\
\mathrm{R}_{1} 5 \mathrm{To}\end{array}$} & \multirow{4}{*}{\multicolumn{4}{|c|}{$\begin{array}{l}\text { A Organic conditioner } R \text { rate } \\
\text { ans control = non add } \\
\text { asse } A_{2} \quad \text { FYM }\end{array}$}} & \\
\hline & $\mathbf{S}$ & 0.92 & 0.06 & 3.74 & & & & & & & \\
\hline & A & 1.29 & 0.81 & 5.29 & & & & & & & \\
\hline & $\mathbf{R}$ & 1.30 & 0.57 & 3.74 & & & & & & & \\
\hline & SA & 1.30 & 1.14 & ns & & & $\begin{array}{l}n \text { refuse } \\
t\end{array}$ & & $\begin{array}{l}\text { A4 Far } \\
\text { compos }\end{array}$ & $\mathrm{n}$ refuse & \\
\hline & SR & 0.92 & ns & ns & & & $n$ fed. ${ }^{-1}$ & & $R_{2} \quad 10$ & Ton fed. & \\
\hline & AR & 1.23 & $\mathrm{~ns}$ & ns & & & & & & & \\
\hline & SAR & 1.83 & ns & ns & & & & & & & \\
\hline
\end{tabular}

\section{Phosphorus uptake by maize plant}

Values of P-uptake by maize plants increased with application of the used manures and the increases were higher by increasing of the applied manures the rate of in both the calcareous clay loamy and the non calcareous sandy soils. Values of P-uptake by shoot and grain of maize plants grown on the calcareous clay loamy soil increased by about (111.29, $96.91,70.00$ and $108.25 \%)$ and $(68.55,27.33,12.42$ and $33.20 \%)$ for straw and grain, respectively. In the non calcareous sandy soil, these values reached $(44.30,22.76,18.91$ and 16.08\%) and $(59.35,26.98,9.23$ and $13.29 \%$ ) for the above mentioned parameters, respectively. The highest $\mathrm{P}$ uptake by maize plant was obtained due to application of vinasse in both the calcareous clay loamy and non calcareous sandy soils. These results may be because the application of the used manures enhanced the availability of $N$, $\mathrm{P}$ and $\mathrm{K}$ in soil and consequently their uptake by plants. This conclusion stands in well agreement with those of El-Fayoumy et al. (2001) who pointed out that application of different organic amendments to calcareous clay loamy soil increased corn grain yield and the uptake of N, P and K. Habib et al. (2001b) stated that N, P and K uptake by wheat and sudan grass growing on calcareous clay loamy soil as well as their dry matter yield were improved by increasing the application of farm refuse compost (sugar beet residues and farm refuse composted for 6 months). 
Table 7: Effect of the used organic materials (soil conditioners) on N, P and $\mathrm{K}$ uptake $\left(\mathrm{Kg} / \mathrm{fed} .^{-1}\right)$ by grain of maize plant grown on the investigated soils.

\begin{tabular}{|c|c|c|c|c|c|c|c|c|c|c|c|}
\hline \multirow[t]{2}{*}{ item } & \multirow{2}{*}{ Rate } & \multicolumn{5}{|c|}{ The calcareous clay loamy soil } & \multicolumn{5}{|c|}{ The non calcareous sandy soil } \\
\hline & & $\mathbf{A}_{1}$ & $\mathbf{A}_{2}$ & $\mathbf{A}_{3}$ & $A_{4}$ & $\mathbf{M}$ & $\overline{A_{1}}$ & $\mathbf{A}_{2}$ & $A_{3}$ & $\mathbf{A}_{4}$ & $\mathbf{M}$ \\
\hline \multirow{4}{*}{$\underset{(\mathrm{Kg} / \mathrm{fed} .)}{\mathrm{N}}$} & non & \multicolumn{5}{|c|}{17.44} & \multicolumn{5}{|c|}{13.60} \\
\hline & $\mathbf{R}_{1}$ & 25.91 & 19.92 & 17.22 & 23.36 & 21.60 & 21.78 & \begin{tabular}{|l}
13.72 \\
\end{tabular} & 12.90 & 14.72 & 15.78 \\
\hline & $\mathbf{R}_{2}$ & 39.56 & 37.20 & 32.67 & 30.96 & 35.10 & 22.72 & 22.20 & 15.36 & 18.18 & 19.62 \\
\hline & mean & 32.74 & 28.56 & 24.95 & 27.16 & 28.35 & 22.25 & \begin{tabular}{|l|}
17.96 \\
\end{tabular} & 14.13 & \begin{tabular}{|l|l|}
16.45 \\
\end{tabular} & 17.70 \\
\hline \multirow{4}{*}{$\begin{array}{c}p \\
\text { (Kg/fed.) }\end{array}$} & non & \multicolumn{5}{|c|}{9.90} & \multicolumn{5}{|c|}{5.20} \\
\hline & $\overline{\mathbf{R}_{1}}$ & 15.24 & 9.96 & 8.38 & 8.76 & \begin{tabular}{l|l}
10.59 \\
\end{tabular} & 7.92 & 5.88 & 5.36 & 5.52 & 6.17 \\
\hline & $\mathbf{R}_{2}$ & 18.13 & 15.25 & 13.88 & 15.89 & 15.79 & 8.65 & 7.33 & 6.00 & 6.26 & 7.06 \\
\hline & mean & 16.69 & 12.61 & 11.13 & 12.32 & 13.19 & 8.29 & 6.60 & 5.68 & 5.89 & 6.62 \\
\hline \multirow{4}{*}{$\begin{array}{c}\mathrm{K} \\
\text { (Kg/fed.) }\end{array}$} & non & \multicolumn{5}{|c|}{20.00} & \multicolumn{5}{|c|}{8.50} \\
\hline & $\mathbf{R}_{1}$ & 32.67 & 25.19 & 22.84 & 24.60 & 26.32 & 11.88 & 9.80 & 8.72 & 10.36 & 10.19 \\
\hline & $\mathbf{R}_{2}$ & 38.96 & 36.04 & 26.85 & 35.64 & 34.37 & 18.54 & 13.32 & 10.68 & 12.12 & 13.67 \\
\hline & mean & 35.82 & 30.61 & 24.85 & 30.12 & 30.35 & 15.21 & 11.56 & 9.70 & \begin{tabular}{|l|}
11.24 \\
\end{tabular} & 11.93 \\
\hline \multicolumn{2}{|c|}{ LSD at 0.05} & $\mathrm{~N}$ & $\mathrm{P}$ & $\mathrm{K}$ & \multirow{8}{*}{\multicolumn{7}{|c|}{ 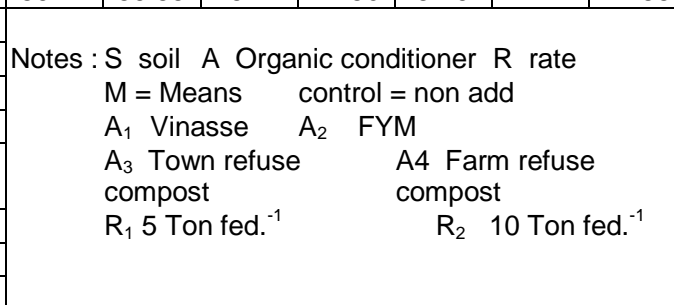 }} \\
\hline & S & 0.69 & 1.24 & 0.69 & & & & & & & \\
\hline & A & 0.58 & 1.73 & 0.35 & & & & & & & \\
\hline & $\mathbf{R}$ & 0.81 & 2.48 & 0.35 & & & & & & & \\
\hline & SA & 1.18 & 1.24 & ns & & & & & & & \\
\hline & SR & 0.58 & 1.73 & 0.34 & & & & & & & \\
\hline & AR & 0.83 & ns & 0.69 & & & & & & & \\
\hline & SAR & 1.00 & ns & 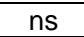 & & & & & & & \\
\hline
\end{tabular}

\section{Phosphorus uptake by wheat plant}

Values of P-uptake by wheat plants increased wing application of the used manures and the increases became more obvious by increasing rate of applied manures in both the calcareous clay loamy and the non calcareous sandy soils. In addition, results declared that efficiency of the studied materials varied in accordance with type and rate of the applied manures. The residual effect of the used manures A1 (vinasse), A2 (FYM), A3 (town refuse compost), A4 (farm refuse compost), enhanced the P-uptake by both shoots and grains of wheat plants. Values of P-uptake by shoot and grain of wheat plants grown on the calcareous clay loamy soil increased by about $(74.75,173.94,97.82$ and $157.60 \%)$ and $(109.360,209.28,118.80$ and $147.82 \%)$ for straw and grain, respectively. In the non calcareous sandy soil, these values reached $(55.42,116.00,42.70$ and $94.73 \%)$ and (97.55, $137.68,83.40$ and $140.23 \%)$ for the above mentioned parameters, respectively.

The highest P-uptake value by wheat straw was recorded owing to application of the farm refuse compost and FYM, respectively in both the investigated soils. However, the highest P-uptake by wheat grain was caused due to the residual effect of FYM in both the investigated soils. These results may be due to the residual effect of those applied manures which enhanced the availability of $P$ in soils and consequently its uptake by plants. However, the residual effect of the FYM or farm refuse compost was more obvious than 
town refuse compost or vinasse. This conclusion stands in well agreement with those of Myungsu et al. (2004) who showed that the higher level of $P$ remaining in soil is accumulated by long-term annual application of farm refuse compost than by that chemical fertilizer, and $\mathrm{P}$ accumulation might be a gradual saturation of the P-sorption capacity. Meena (2007) reported that farmyard manure as a source of phosphorus was statistically superior to other treatments such as poultry manure (PM), bio farm refuse compost (BC) and press mud (Pr.m).

Table 8: Effect of the used organic materials (soil conditioners) on N, P and $\mathrm{K}$ uptake $\left(\mathrm{Kg} / \mathrm{fed} .^{-1}\right)$ by grain of wheat plant in yield in investigated soils. plant grown on the investigated soils. plant grown on the investigated soils.

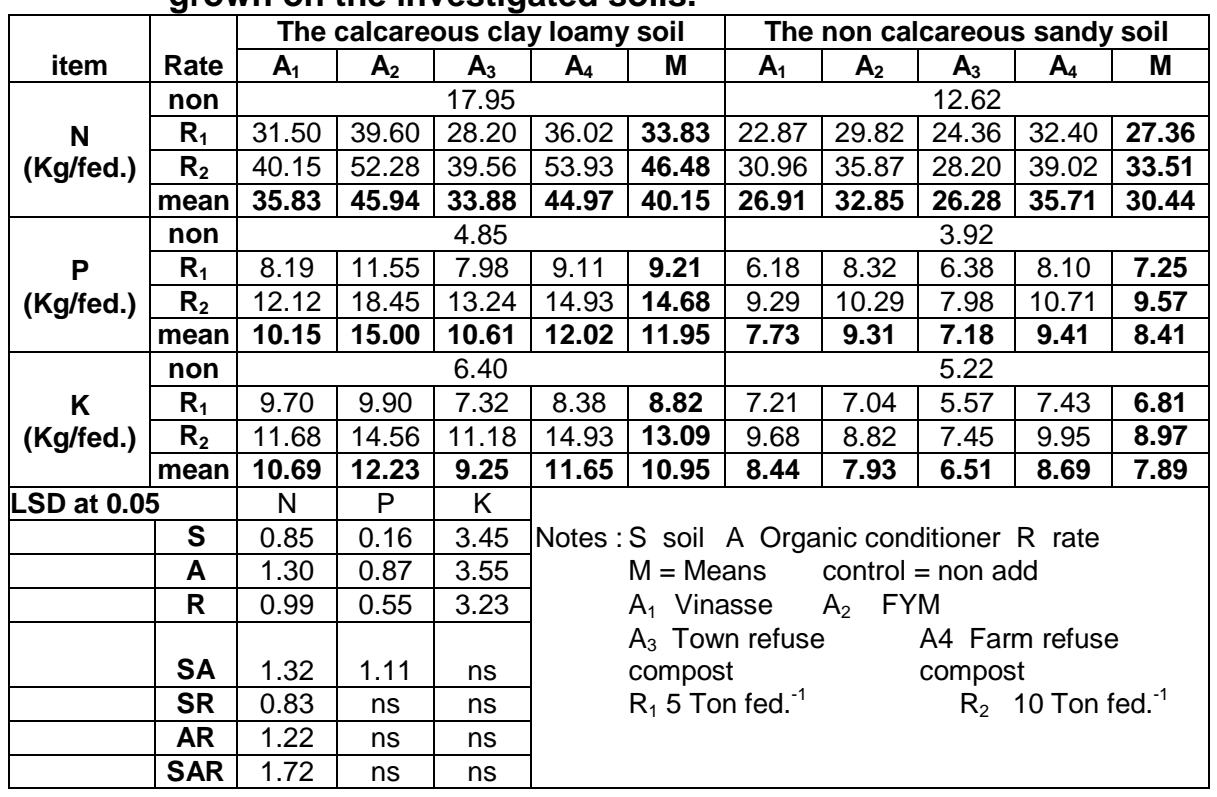

\section{Potassium uptake by maize plant}

Values of K-uptake by maize plants were increased due to application of the used manures and the increase was more obvious by increasing rate of the applied manures to both calcareous clay loamy and non calcareous sandy soils. The applied of manures as A1 (vinasse), A2 (FYM), A3 (town refuse compost), A4 (farm refuse compost), enhanced the K-uptake by both shoots and grains of maize plants. Values of K-uptake by shoot and grain of maize plants grown on the calcareous clay loamy soil increased by about (111.68, 92.60, 75.76 and 133.65.50\%) and (79.08, 53.07, 24.23 and $50.60 \%)$ for straw and grain, respectively. In the non calcareous sandy soil, these values reached $(44.04,51.58,19.02$ and $52.01 \%)$ and $(78.94,36.00$, 14.12 and $32.24 \%)$ for the above mentioned parameters, respectively. The highest K-uptake by maize plant was obtained due to application of vinasse in both the calcareous clay loamy and the non calcareous sandy soils. These 
results may be due to the application of the used manures enhanced the availability of $\mathrm{N}, \mathrm{P}$ and $\mathrm{K}$ in soil and consequently their uptake by plants. Similarly,

Potassium uptake by wheat plant

Values of K-uptake by wheat plants were increased with application of the used manures. The increases were more obvious by increasing rate of the applied manures to both calcareous clay loamy and non calcareous sandy soils. In addition, results showed that efficiency of the studied materials varied owing to type and rate of the applied manures. The residual effect of A1 (vinasse), A2 (FYM), A3 (town refuse compost), A4 (farm refuse compost), enhanced the K-uptake by both shoots and grains of wheat plants. Values of K-uptake by shoot and grain of wheat plants grown on the calcareous clay loamy soil increased by about (115.72, 203.10,127.12 and $209.12 \%)$ and $(66.99,91.00,44.45$ and $82.01 \%)$ for straw and grain, respectively. In the non calcareous sandy soil, these values reached (136.62, $217.00,100.90$ and $172.36 \%)$ and $(61.73,51.92,24.67$ and $66.38 \%)$ for the above mentioned parameters, respectively. The highest K-uptake by straw of wheat plant was recorded due to the residual effect of the vinasse in the calcareous clay loamy and the non calcareous sandy soils. This finding stands in well agreement with those of Adel Rabie and Mohsen (2008) who stated that vinasse added to new reclaimed soil caused a significant decrease in soil $\mathrm{pH}$ and significant increases in soil available $\mathrm{P}$ and $\mathrm{K}$ as well as markedly increased the nutrients utilization by wheat plants.

Effect of the used manures on the micronutritve elements in maize plants .

Results presented in Table 9 and 10 show that the application of the used manures to both the calcareous clay loamy and non calcareous sandy soils caused a marked significantly effect on $\mathrm{Fe}, \mathrm{Cu}, \mathrm{Mn}$ and $\mathrm{Zn}$ uptake by shoot and grain of maize plants. Also, results indicated that the efficiency of the studied manures differed according to its type and rate of application. It is note worthy to mention that application of farm refuse compost resulted in the highest values of $\mathrm{Fe}, \mathrm{Cu}, \mathrm{Mn}$ and $\mathrm{Zn}$ uptake by shoot of maize plants increase percentages reached (306.92, 122.41, 116.26 and $168.26 \%$ ) over the control treatment, respectively.

On the other hand, in the non calcareous sandy soil the highest increment percentages reached (63.34, 88.62, 198.63 and $163.41 \%$ ) due to vinasse application. The data indicated that highest values of $\mathrm{Fe}, \mathrm{Cu}, \mathrm{Mn}$ and $\mathrm{Zn}$ uptake by grain of maize plants grown on the calcareous clay loamy soil were obtained by vinasse application and the highest increment percentages reached $(65.97,27.86,46.82$ and $19.76 \%)$. Contrary to that, in the non calcareous sandy soil, FYM caused the highest uptake values of $\mathrm{Fe}, \mathrm{Zn}$, and $\mathrm{Cu}$ and the increment percentages reached to $(37.20,12.83,28.24$ and $24.87 \%$ ), respectively. 
Habib, F. M. et al.

Table 9: Effect of the used organic materials (soil conditioners) on Fe, $\mathrm{Cu}, \mathrm{Mn}$ and $\mathrm{Zn}$ uptake $\left(\mathrm{Kg} / \mathrm{fed}^{-1}\right)$ by shoots of maize plant grown on the investigated soils.

\begin{tabular}{|c|c|c|c|c|c|c|c|c|c|c|c|}
\hline \multirow[t]{2}{*}{ item } & \multirow[t]{2}{*}{ Rate } & \multicolumn{5}{|c|}{ The calcareous clay loamy soil } & \multicolumn{5}{|c|}{ The non calcareous sandy soil } \\
\hline & & $A_{1}$ & $A_{2}$ & $\mathbf{A}_{3}$ & $\mathbf{A}_{4}$ & $\mathbf{M}$ & $A_{1}$ & $A_{2}$ & $A_{3}$ & $A_{4}$ & $\mathbf{M}$ \\
\hline \multirow{4}{*}{$\begin{array}{c}\mathrm{Fe} \\
(\mathrm{Kg} / \mathrm{fed} .)\end{array}$} & non & \multicolumn{5}{|c|}{0.73} & \multicolumn{5}{|c|}{0.57} \\
\hline & $\mathbf{R}_{1}$ & 2.88 & 1.82 & 1.67 & 2.47 & 2.21 & 0.75 & 0.80 & 0.66 & 0.81 & 0.75 \\
\hline & $\mathbf{R}_{2}$ & 4.62 & 3.81 & 2.52 & 4.08 & 3.76 & 1.80 & 0.90 & 0.78 & 0.93 & 1.10 \\
\hline & mean & 3.75 & 2.81 & 2.10 & 3.28 & 2.98 & 1.27 & 0.85 & 0.72 & 0.87 & 0.93 \\
\hline \multirow{4}{*}{$\begin{array}{c}\mathrm{Cu} \\
\text { (Kg/fed.) }\end{array}$} & non & \multicolumn{5}{|c|}{0.31} & \multicolumn{5}{|c|}{0.24} \\
\hline & $\mathbf{R}_{1}$ & 0.70 & 0.40 & 0.36 & 0.57 & 0.51 & 0.32 & 0.42 & 0.39 & 0.43 & 0.39 \\
\hline & $\mathbf{R}_{2}$ & 0.97 & 0.82 & 0.61 & 1.09 & 0.88 & 0.57 & 0.56 & 0.45 & 0.50 & 0.52 \\
\hline & mean & 0.84 & 0.61 & 0.49 & 0.83 & 0.69 & 0.44 & 0.49 & 0.42 & 0.46 & 0.45 \\
\hline \multirow{4}{*}{$\begin{array}{c}\text { Mn } \\
\text { (Kg/fed.) }\end{array}$} & non & \multicolumn{5}{|c|}{0.15} & \multicolumn{5}{|c|}{0.06} \\
\hline & $\mathbf{R}_{1}$ & 0.34 & 0.23 & 0.20 & 0.30 & 0.27 & 0.11 & 0.15 & 0.09 & 0.14 & 0.12 \\
\hline & $\mathbf{R}_{2}$ & 0.51 & 0.28 & 0.25 & 0.45 & 0.37 & 0.23 & 0.24 & 0.16 & 0.25 & 0.22 \\
\hline & mean & 0.42 & 0.26 & 0.22 & 0.38 & 0.32 & 0.17 & 0.19 & 0.12 & 0.20 & 0.17 \\
\hline \multirow{4}{*}{$\underset{\text { (Kg/fed.) }}{\mathrm{Zn}}$} & non & \multicolumn{5}{|c|}{0.28} & \multicolumn{5}{|c|}{0.14} \\
\hline & $\mathbf{R}_{1}$ & 0.78 & 0.35 & 0.33 & 0.72 & 0.55 & 0.34 & 0.28 & 0.15 & 0.30 & 0.27 \\
\hline & $\mathbf{R}_{2}$ & 1.11 & 0.85 & 0.63 & 1.25 & 0.96 & 0.61 & 0.45 & 0.31 & 0.50 & 0.46 \\
\hline & mean & 0.95 & 0.60 & 0.48 & 0.99 & 0.75 & 0.47 & 0.37 & 0.23 & 0.40 & 0.37 \\
\hline \multicolumn{2}{|l|}{ LSD at 0.05} & $\mathrm{Fe}$ & $\mathrm{Cu}$ & $\mathrm{Mn}$ & $\mathrm{Zn}$ & \multirow{8}{*}{\multicolumn{6}{|c|}{$\begin{array}{c}\text { Notes : } S \text { soil } A \text { Organic conditioner } R \text { rate } \\
M=\text { Means control }=\text { non add } \\
\begin{array}{ll}A_{1} \text { Vinasse } \quad A_{2} & F Y M \\
A_{3} \text { Town refuse } & A 4 \text { Farm } \\
\text { compost } & \text { refuse compost } \\
R_{1} 5 \text { Ton fed. } .^{-1} & R_{2} 10 \text { Ton fed }^{-1}\end{array}\end{array}$}} \\
\hline & $\mathbf{S}$ & 0.52 & 0.67 & 2.24 & 2.10 & & & & & & \\
\hline & A & 1.92 & 0.91 & 2.76 & 2.14 & & & & & & \\
\hline & $\mathbf{R}$ & 3.13 & 1.25 & 2.28 & 2.35 & & & & & & \\
\hline & SA & 2.26 & 0.67 & 1.44 & 1.20 & & & & & & \\
\hline & SR & 2.92 & 1.35 & 1.79 & 1.90 & & & & & & \\
\hline & AR & 4.45 & 1.40 & 3.48 & 3.58 & & & & & & \\
\hline & SAR & 5.15 & 1.52 & 4.52 & 5.10 & & & & & & \\
\hline
\end{tabular}

These results may be due to the positive effect FYM on the bioreleaser of the plant nutrients and their availability to be take up by the growing plant. These results are in harmony with those reported by Wahdan et al. (2006) who found that the favorable conditions achieved in soil as a result of the applied organic manure are commonly associated with lowering soil $\mathrm{pH}$ and forming organo-metalic compounds (i.e., the chelated micronutrients), which represented the next superior form due to a higher portion of these compounds is still maintained in active forms for uptake by plant roots. In addition, adding organic manure increased crop productivity as a result of increasing soil bio-availability of micronutrients (i.e., $\mathrm{Fe}, \mathrm{Mn}$, $\mathrm{Zn}$ and $\mathrm{Cu}$ ) and cation exchange capacity in the newly reclaimed soils, and in turn markedly increased the dry weight and the plant contents of these nutrients at the vegetative growth of maize. 
Table 10: Effect of the used organic materials (soil conditioners) on Fe, $\mathrm{Cu}, \mathrm{Mn}$ and $\mathrm{Zn}$ uptake (g/fed. $\left.{ }^{-1}\right)$ by maize grains of plant grown on the investigated soils.

\begin{tabular}{|c|c|c|c|c|c|c|c|c|c|c|c|}
\hline \multirow[t]{2}{*}{ item } & \multirow[t]{2}{*}{ Rate } & \multicolumn{5}{|c|}{ The calcareous clay loamy soil } & \multicolumn{5}{|c|}{ The non calcareous sandy soil } \\
\hline & & $\mathbf{A}_{1}$ & $\mathbf{A}_{2}$ & $\mathbf{A}_{3}$ & $\mathbf{A}_{4}$ & $\mathbf{M}$ & $A_{1}$ & $A_{2}$ & $\mathbf{A}_{3}$ & $\mathbf{A}_{4}$ & $\mathbf{M}$ \\
\hline \multirow{4}{*}{$\begin{array}{c}F e \\
\text { (g/fed.) }\end{array}$} & non & \multicolumn{5}{|c|}{235.00} & \multicolumn{5}{|c|}{163.90} \\
\hline & $\mathbf{R}_{1}$ & 418.72 & 375.89 & 367.89 & 323.54 & 371.51 & 215.62 & 213.25 & 179.59 & 203.8 & 203.08 \\
\hline & $\mathbf{R}_{\mathbf{2}}$ & 464.74 & 429.66 & 331.16 & 408.67 & 408.56 & 288.25 & 254.19 & 210.24 & 233.92 & 246.65 \\
\hline & mean & 1.73 & 402.78 & 349.53 & 366.11 & 390.03 & 251.94 & 233.72 & 194.92 & & 224.87 \\
\hline \multirow{4}{*}{$\underset{\text { (g/fed.) }}{\mathrm{Cu}}$} & non & \multicolumn{5}{|c|}{19.81} & \multicolumn{5}{|c|}{16.85} \\
\hline & $\mathbf{R}_{1}$ & 27.15 & 21.58 & 21.19 & 23.72 & 23.41 & 18.71 & 18.72 & 17.56 & 18.36 & 18.34 \\
\hline & $\mathbf{R}_{2}$ & 29.78 & 28.23 & 23.96 & 27.03 & 27.25 & 19.64 & 20.35 & 18.95 & 19.80 & 19.69 \\
\hline & mean & 28.47 & 24.91 & 22.58 & 25.38 & 25.33 & 19.18 & 19.54 & 18.26 & 19.08 & 19.01 \\
\hline \multirow{4}{*}{$\underset{(\mathrm{g} / \mathrm{fed} .)}{\operatorname{Mn}}$} & non & \multicolumn{5}{|c|}{135.16} & \multicolumn{5}{|c|}{96.95} \\
\hline & $\mathbf{R}_{1}$ & 151.82 & 156.63 & 186.00 & 184.96 & 169.85 & 124.11 & 123.48 & 106.85 & 117.02 & 117.87 \\
\hline & $\mathbf{R}_{2}$ & 261.62 & 237.34 & 189.43 & 219.78 & 227.04 & 130.60 & 141.53 & 122.40 & 128.65 & 130.80 \\
\hline & mean & 206.72 & 196.99 & $\mid 187.72$ & 202.37 & 198.45 & 127.36 & 132.51 & 114.63 & 12 & 4.33 \\
\hline \multirow{4}{*}{$\underset{\text { (g/fed.) }}{\mathrm{Zn}}$} & non & \multicolumn{5}{|c|}{39.60} & \multicolumn{5}{|c|}{21.11} \\
\hline & $\mathbf{R}_{1}$ & \begin{tabular}{|l|}
51.82 \\
\end{tabular} & 44.09 & 43.58 & 42.00 & 45.37 & 26.63 & 24.64 & 22.76 & 24.84 & 24.72 \\
\hline & $\mathbf{R}_{2}$ & 56.86 & 51.71 & 41.52 & 47.82 & 49.48 & 28.22 & 29.64 & 26.27 & 27.88 & 28.00 \\
\hline & mean & \begin{tabular}{|l|l}
54.34 \\
\end{tabular} & 47.90 & 42.55 & 44.91 & 47.43 & 27.43 & 27.14 & 24.52 & 26.36 & 26.36 \\
\hline \multicolumn{2}{|c|}{ LSD at 0.05} & $\mathrm{Fe}$ & $\mathrm{Cu}$ & $\mathrm{Mn}$ & $\mathrm{Zn}$ & \multirow{8}{*}{\multicolumn{6}{|c|}{ 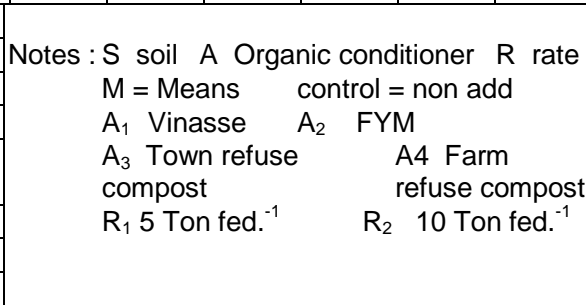 }} \\
\hline & S & 0.66 & 0.87 & 2.35 & 2.20 & & & & & & \\
\hline & A & 2.10 & 1 & 2.32 & 3.10 & & & & & & \\
\hline & $\mathbf{R}$ & 3.30 & 2.10 & 2.19 & 2.55 & & & & & & \\
\hline & SA & 2.10 & 0.55 & 1.32 & 1.30 & & & & & & \\
\hline & SR & 2.65 & 1.30 & 1.36 & 2.10 & & & & & & \\
\hline & AR & 2.30 & 1.20 & 4.10 & 3.26 & & & & & & \\
\hline & SAR & 4.25 & 2.21 & 3.26 & 4.12 & & & & & & \\
\hline
\end{tabular}

The residual effect of the used organic materials (soil conditioners) on the micronutritve elements in wheat plants.

Data of Table 11 and 12 show that the wheat straw and grain uptake vales of $\mathrm{Fe}, \mathrm{Cu}, \mathrm{Mn}$ and $\mathrm{Zn}$ as influenced by the residual effect of the applied manures are presented. These data revealed these effects were significant on vales of $\mathrm{Fe}, \mathrm{Cu}, \mathrm{Mn}$ and $\mathrm{Zn}$ uptake by both straw and grain of wheat plants grown on both investigated soils. In the calcareous clay loamy soil, results show that the highest percentage values of $\mathrm{Fe}, \mathrm{Cu}, \mathrm{Mn}$ and $\mathrm{Zn}$ uptake by straw of wheat plants increase percentages reached $(44.13,54.63,117.50$ and $99.46 \%$ ) over the control treatment, respectively due to residual effect of farm refuse compost. On the other hand in the calcareous clay loamy soil the FYM gave the highest values of $\mathrm{Fe}, \mathrm{Cu}, \mathrm{Mn}$ and $\mathrm{Zn}$ uptake by straw of wheat plants and the increment percentages reached $(74.17,40.00,77.50$ and $88.54 \%$ ), respectively. Concerning $\mathrm{Fe}, \mathrm{Cu}, \mathrm{Mn}$ and $\mathrm{Zn}$ uptake by grain of wheat plants data, revealed that application FYM recorded the highest values of $\mathrm{Fe}, \mathrm{Cu}, \mathrm{Mn}$ and $\mathrm{Zn}$ uptake where the increment percentages reached $(91.82,91.98,76.79$ and $81.77 \%)$, respectively.

On the other hand, in calcareous clay loamy soil, the residual effect of the applied refuse compost caused the highest values of $\mathrm{Fe}, \mathrm{Cu}, \mathrm{Mn}$ and 
Habib, F. M. et al.

Zn uptake by grain where the increment percentages reached $(53.58,72.25$, 57.66 and 83.96), respectively. It is well known that, during the decomposition of organic matter, macro and micronutrients are incorporated into the soil matrix, allowing the soil to act as a reservoir for these nutrients. These nutrients will be released, to become available for uptake by plants. (ElGhamry et al. 2009).

Table 11: Effect of the used organic materials (soil conditioners) on Fe, $\mathrm{Cu}, \mathrm{Mn}$ and $\mathrm{Zn}$ uptake $\left(\mathrm{Kg} / \mathrm{fed} .^{-1}\right)$ by straw of wheat grown on the investigated soils.

\begin{tabular}{|c|c|c|c|c|c|c|c|c|c|c|c|}
\hline \multirow[t]{2}{*}{ Item } & \multirow[t]{2}{*}{ Rate } & \multicolumn{5}{|c|}{ The calcareous clay loamy soil } & \multicolumn{5}{|c|}{ The non calcareous sandy soil } \\
\hline & & $\mathbf{A}_{1}$ & $\mathbf{A}_{2}$ & $\mathbf{A}_{3}$ & $\mathbf{A}_{4}$ & $\mathbf{M}$ & $\mathbf{A}_{1}$ & $\mathbf{A}_{2}$ & $\mathbf{A}_{3}$ & $\mathbf{A}_{4}$ & $\mathbf{M}$ \\
\hline \multirow{4}{*}{$\begin{array}{c}\mathrm{Fe} \\
\text { (Kg/fed.) }\end{array}$} & non & \multicolumn{5}{|c|}{0.78} & \multicolumn{5}{|c|}{0.30} \\
\hline & $\mathbf{R}_{1}$ & 0.93 & 0.97 & 0.84 & 1.03 & 0.94 & 0.51 & 0.46 & 0.37 & 0.38 & 0.43 \\
\hline & $\mathbf{R}_{2}$ & 1.42 & 1.47 & 0.91 & 1.42 & 1.31 & 0.60 & 0.72 & 0.52 & 0.62 & 0.62 \\
\hline & mean & 1.18 & 1.22 & 0.88 & 1.23 & 1.12 & 0.56 & 0.59 & 0.45 & 0.50 & 0.52 \\
\hline \multirow{4}{*}{$\begin{array}{c}\text { Cu } \\
\text { (g/fed.) } \\
\text { (Kg/fed.) }\end{array}$} & non & \multicolumn{5}{|c|}{0.17} & \multicolumn{5}{|c|}{0.15} \\
\hline & $\mathbf{R}_{1}$ & 0.23 & 0.23 & 0.18 & 0.28 & 0.23 & 0.16 & 0.22 & 0.18 & 0.16 & 0.18 \\
\hline & $\mathbf{R}_{2}$ & 0.30 & 0.31 & 0.23 & 0.34 & 0.30 & 0.22 & 0.31 & 0.21 & 0.22 & 0.24 \\
\hline & mean & 0.27 & 0.27 & 0.21 & 0.31 & 0.26 & 0.19 & 0.27 & 0.20 & 0.19 & 0.21 \\
\hline \multirow{4}{*}{$\begin{array}{c}\text { Mn } \\
\text { (Kg/fed.) }\end{array}$} & non & \multicolumn{5}{|c|}{0.16} & \multicolumn{5}{|c|}{0.10} \\
\hline & $\mathbf{R}_{1}$ & 0.26 & 0.32 & 0.24 & 0.39 & 0.30 & 0.16 & 0.17 & 0.12 & 0.13 & 0.15 \\
\hline & $\mathbf{R}_{2}$ & 0.34 & 0.43 & 0.32 & 0.48 & 0.39 & 0.19 & 0.29 & 0.17 & 0.19 & 0.21 \\
\hline & mean & 0.30 & 0.38 & 0.28 & 0.44 & 0.35 & 0.18 & 0.23 & 0.15 & 0.16 & 0.18 \\
\hline \multirow{4}{*}{$\begin{array}{c}\mathrm{Zn} \\
\text { (Kg/fed.) }\end{array}$} & non & \multicolumn{5}{|c|}{0.23} & \multicolumn{5}{|c|}{0.12} \\
\hline & $R_{1}$ & 0.37 & 0.47 & 0.28 & 0.49 & 0.40 & 0.18 & 0.19 & 0.18 & 0.18 & 0.18 \\
\hline & $\mathbf{R}_{2}$ & 0.53 & 0.55 & 0.37 & 0.61 & 0.52 & 0.26 & 0.31 & 0.22 & 0.29 & 0.27 \\
\hline & mean & 0.45 & 0.51 & 0.33 & 0.55 & 0.46 & 0.22 & 0.25 & 0.20 & 0.24 & 0.23 \\
\hline \multicolumn{2}{|l|}{ LSD at 0.05} & $\mathrm{Fe}$ & $\mathrm{Cu}$ & $\mathrm{Mn}$ & $\mathrm{Zn}$ & \multirow{8}{*}{\multicolumn{6}{|c|}{ 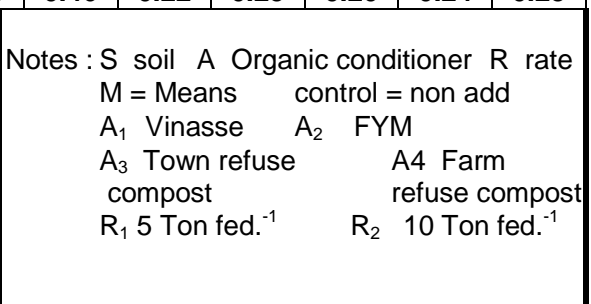 }} \\
\hline & $\mathbf{S}$ & 0.92 & 0.06 & 3.74 & 0.35 & & & & & & \\
\hline & A & 1.49 & 0.85 & 4.29 & 2.21 & & & & & & \\
\hline & R & 1.30 & 0.87 & 4.74 & 2.14 & & & & & & \\
\hline & SA & 1.30 & 3.14 & ns & 3.10 & & & & & & \\
\hline & SR & 0.82 & $\mathrm{~ns}$ & $\mathrm{~ns}$ & ns & & & & & & \\
\hline & AR & 1.03 & ns & ns & ns & & & & & & \\
\hline & SAR & 1.75 & ns & ns & ns & & & & & & \\
\hline
\end{tabular}


Table 12: Effect of the used organic materials (soil conditioners) on Fe, $\mathrm{Cu}, \mathrm{Mn}$ and $\mathrm{Zn}$ uptake $\left(\mathrm{Kg} / \mathrm{fed}^{-1}\right)$ by grain of wheat plant grown on the investigated soils.

\begin{tabular}{|c|c|c|c|c|c|c|c|c|c|c|c|}
\hline \multirow[t]{2}{*}{ item } & \multirow[t]{2}{*}{ Rate } & \multicolumn{5}{|c|}{ The calcareous clay loamy soil } & \multicolumn{5}{|c|}{ The non calcareous sandy soil } \\
\hline & & $A_{1}$ & $A_{2}$ & $\mathbf{A}_{3}$ & $\mathbf{A}_{4}$ & $\mathbf{M}$ & $A_{1}$ & $A_{2}$ & $A_{3}$ & $\mathbf{A}_{4}$ & $\mathbf{M}$ \\
\hline \multirow{4}{*}{$\begin{array}{c}\mathrm{Fe} \\
(\mathrm{Kg} / \mathrm{fed} .)\end{array}$} & non & \multicolumn{5}{|c|}{0.12} & \multicolumn{5}{|c|}{0.11} \\
\hline & $\mathbf{R}_{1}$ & 0.16 & 0.23 & 0.18 & 0.20 & 0.19 & 0.13 & 0.16 & 0.15 & 0.17 & 0.15 \\
\hline & $\mathbf{R}_{2}$ & 0.19 & 0.30 & 0.24 & 0.29 & 0.25 & 0.17 & 0.19 & 0.18 & 0.21 & 0.19 \\
\hline & mean & 0.18 & 0.26 & 0.21 & 0.25 & 0.22 & 0.15 & 0.18 & 0.16 & 0.19 & 0.17 \\
\hline \multirow{4}{*}{$\begin{array}{c}\mathrm{Cu} \\
\text { (Kg/fed.) }\end{array}$} & non & \multicolumn{5}{|c|}{0.04} & \multicolumn{5}{|c|}{0.03} \\
\hline & $\mathbf{R}_{1}$ & 0.06 & 0.08 & 0.06 & 0.07 & 0.07 & 0.05 & 0.06 & 0.05 & 0.06 & 0.05 \\
\hline & $\mathbf{R}_{2}$ & 0.07 & 0.10 & 0.08 & 0.10 & 0.09 & 0.06 & 0.07 & 0.06 & 0.07 & 0.07 \\
\hline & mean & 0.06 & 0.09 & 0.07 & 0.09 & 0.08 & 0.05 & 0.07 & 0.05 & 0.07 & 0.06 \\
\hline \multirow{4}{*}{$\begin{array}{c}\text { Mn } \\
\text { (Kg/fed.) }\end{array}$} & non & \multicolumn{5}{|c|}{0.07} & \multicolumn{5}{|c|}{0.06} \\
\hline & $\mathbf{R}_{1}$ & 0.09 & 0.12 & 0.09 & 0.11 & 0.10 & 0.07 & 0.09 & 0.08 & 0.09 & 0.08 \\
\hline & $\mathbf{R}_{2}$ & 0.11 & 0.15 & 0.12 & 0.15 & 0.14 & 0.09 & 0.11 & 0.10 & 11 & 0.10 \\
\hline & mean & 0.10 & 0.14 & 0.11 & 0.13 & 0.12 & 0.08 & 0.10 & 0.09 & 0.10 & 0.09 \\
\hline \multirow{4}{*}{$\begin{array}{c}\mathrm{Zn} \\
\text { (Kg/fed.) }\end{array}$} & non & \multicolumn{5}{|c|}{0.03} & \multicolumn{5}{|c|}{0.02} \\
\hline & $\mathbf{R}_{1}$ & 0.03 & 0.05 & 0.04 & 0.05 & 0.04 & 0.03 & 0.04 & 0.03 & 0.04 & 0.04 \\
\hline & $\mathbf{R}_{2}$ & 0.04 & 0.06 & 0.05 & 0.07 & 0.06 & 0.04 & 0.05 & 0.04 & 0.05 & 0.05 \\
\hline & mean & 0.04 & 0.05 & 0.04 & 0.06 & 0.05 & 0.03 & 0.05 & 0.04 & 0.05 & 0.04 \\
\hline \multicolumn{2}{|c|}{ LSD at 0.05} & $\mathrm{Fe}$ & $\mathrm{Cu}$ & $\mathrm{Mn}$ & $\mathrm{Zn}$ & \multirow{8}{*}{\multicolumn{6}{|c|}{ 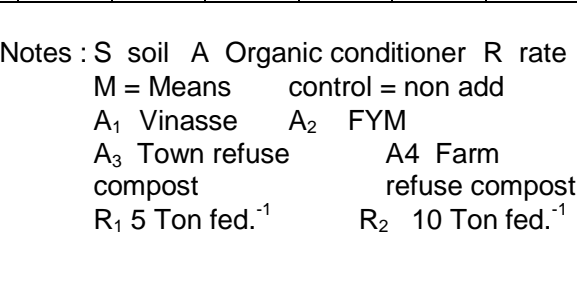 }} \\
\hline & $\mathbf{S}$ & 1.92 & 2.57 & 3.54 & 0.55 & & & & & & \\
\hline & A & 1.59 & 0.75 & 3.29 & 1.21 & & & & & & \\
\hline & $\mathbf{R}$ & 1.70 & \begin{tabular}{|l|}
0.67 \\
\end{tabular} & 3.74 & 1.14 & & & & & & \\
\hline & SA & 1.53 & 3.24 & ns & 2.10 & & & & & & \\
\hline & SR & 0.92 & $\mathrm{~ns}$ & $\mathrm{~ns}$ & ns & & & & & & \\
\hline & AR & 1.63 & ns & ns & ns & & & & & & \\
\hline & SAR & 1.75 & ns & ns & $\mathrm{ns}$ & & & & & & \\
\hline
\end{tabular}

\section{REFERENCES}

Abdas, H.H.; A.H. Abdel-Hameed; E.H.A. Nofal and M. F. Abdel-Aziz (2009) Induced of cattle waste combined with elemental sulphur, nitrogen and phosphorus on wheat succeeded by maize grown on a calcareous clay- loamy soil. Agric. Sci. Mansoura Univ., 34(1):597-610.

Adel Rabie, A. U and A. E. G. Mohsen (2008). Effect of sugar industry wastes on $\mathrm{K}$ status and nutrient availability of a newly reclaimed loamy non calcareous sandy soil. Archives of Agronomy and Soil Science, 54 (6): 665-679.

Bauer, A. and A.L. Black. (1994). Quantification of the effect of soil organic matter content on soil productivity. Soil Sci. Soc. Am. J., 58:185-193.

Black, C.A. (1965). "Methods of Soil Analysis" Part 1. Physical and mineralogical properties including statistics of measurements and sampling. Amer. Soc. of agronomy. Inc. Publisher Madison, Wisconsin, USA.

Carl J. R. and M. B. Peter (2005). Using manure and farm refuse compost as nutrient sources for vegetable crops. Agricultural, Food and Environmental Sciences., 1-12. 
Carter, M.R. and B.A. Stewart (Eds.), (1996). Structure and Organic Matter Storage in Agricultural Soils. CRC Press, Boca Raton. Madison, WI, pp. 443-461.

El-Fayoumy, M.E.; H.M. Ramadan and El. A. El Shanawany. (2001). Calcareous loamy soil Amelioration as affected by different sources of soil amendments. J. Agric. Sci. Mansoura Univ., 26(5):3301-3315.

El-Ghamry, A.M.; A.M. Abd El-Hamid and A.A. Mosa (2009). Effect of farmyard manure and foliar application of micronutrients on yield characteristics of wheat grown on salt affected soil. American-Eurasian J. Agric. \& Environ. Sci., 5 (4): 460-465.

Franzluebbers, A.J. (2002). Water infiltration and soil structure related to organic matter and its stratification with depth. Soil Till. Res., 66: 97205.

Habib, F. M.; A.H. Abd El-Hameed; M.S. Awaad and T.H.M.A. Deshesh (2009) Effect of some organic conditioners on Some chemical and physical properties of newly reclaimed soils in Egypt. Agric. Sci. Mansoura Univ., 34(12):11501-11511.

Habib, F.M.; M.A. Negm and M.M. Hassan (2001b). Farm refuse composting of sugar beet residues. 3- The effect of application dose to a calcareous clay loamysoil on plant growth and nutrient uptake. Egypt. J. Agric. Res., 79 (4): 1263-1275.

Heluf, G. (2002). Progress Research Report (2000/2001) of the Soil and Water Management Research Program , Alemaya Research Center, Alemaya University. 95p

Judith, N.; M. H. Chantigny; A. N. Dayegamiye and M. R. Laverdière (2009). Dairy cattle from soil amended with municipal solid waste farm refuse compost. Journal of Environmental Quality $28: 1074-1082$.

Krishna B. K. (2006). City Waste, farm refuses compost and sustainability of rice-wheat cropping system. Nepal Agric. Res. J. 7: 49-52.

Meena, S., P. Senthilvalavan, M. Malarkodi and R.K. Kaleeswari (2007). Residual effect of phosphorus from organic manures in Sunflower Assessment Using Radio Tracer Technique. Research Journal of Agriculture and Biological Sciences, 3(5): 377-379.

Myungsu, P.; Singvilay O.; Shin W.; Kim E.; Chung J. and T. Sa (2004). Effect of long-term compost and fertilizer application on soil phosphorus status under paddy cropping system. Comm. In Soil Science and Plant Anlalysis. 35, (11\&12): 1635-1644.

Sardoui, J. S., A. Ronaghi , M. Maftoun , and N. Karimian (2003). Growth and chemical composition of corn in three calcareous clay loamy non calcareous sandy soils of Iran as affected by applied phosphorus and manure. J. Agric. Sci. Technol., 5: 77-84.

Snedecer, G. W and W.G., Coshran (1982). "Statistical Methods" 7th ed.p593. lowa state univ. press, Ames., lowa, U.S.A.

Wahdan, A.A.A.; Awadalla A.A. and M.M. Mahmoud, (2006). Response of some wheat-maize cropping sequence in a calcareous clay loamy soil to some mineral or chelated micronutrient forms added to soil in combination with sulphur and organic manures. Fayoum J. Agric. Res. \& Dev., 20(1):25-39. 
Zebarth, B.J.; Neilsen G.H.; Hogue E. and D. Neilsen (1999). Influence of organic waste amendments on selected soil physical and chemical properties. Can. J. Soil Sci. 79, 501-504.

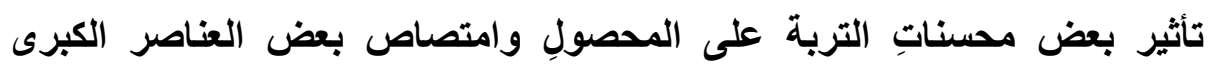

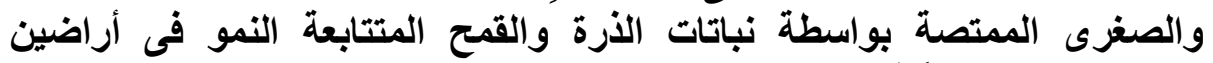

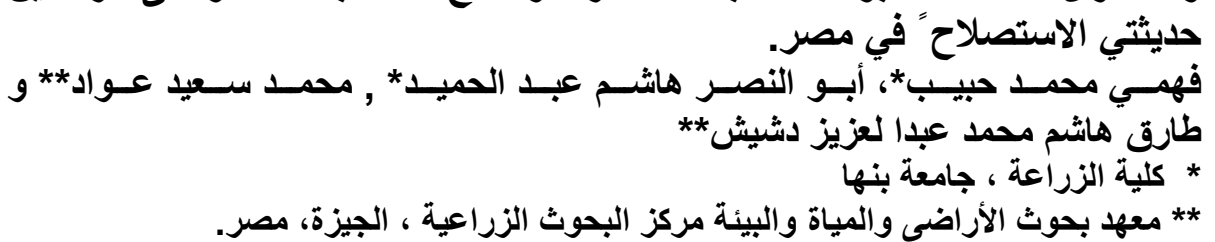

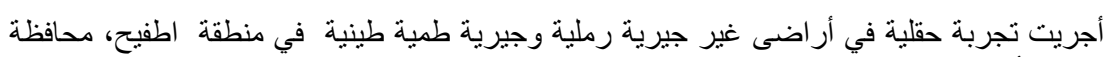

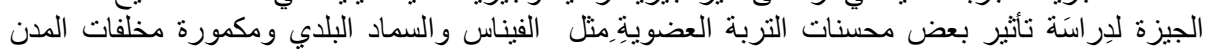

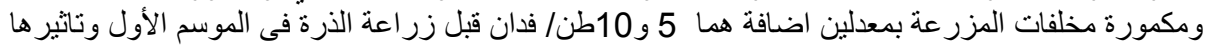

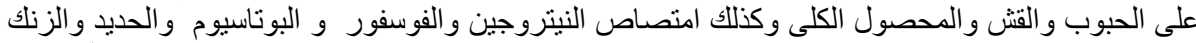

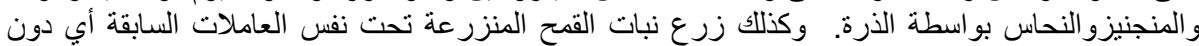

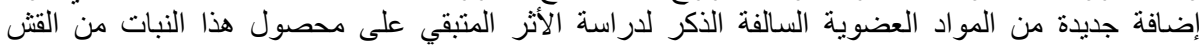

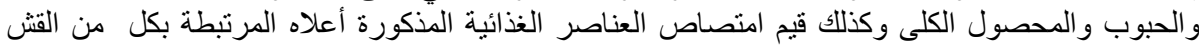

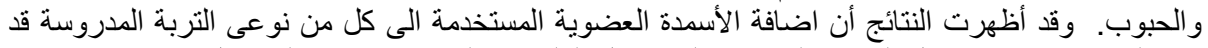

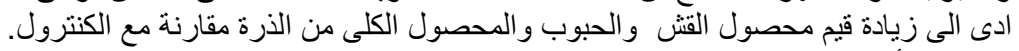

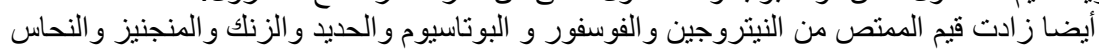

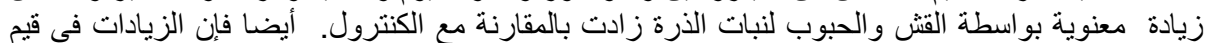

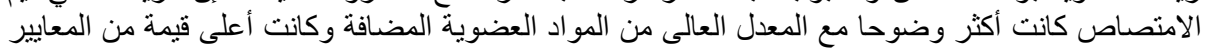
المذكورة قد تحققت مع الفيناس.

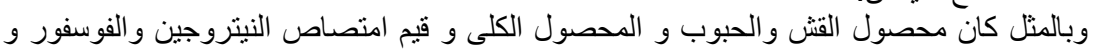

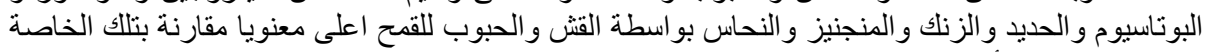

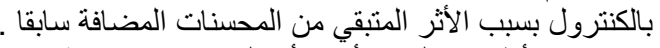

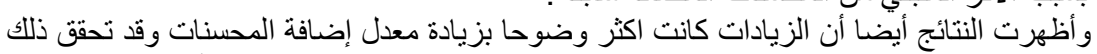

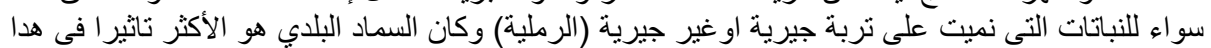

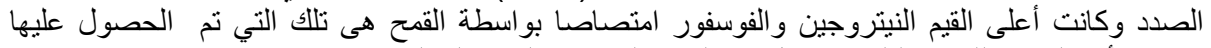

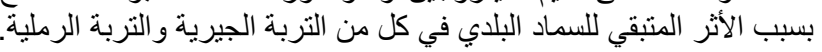

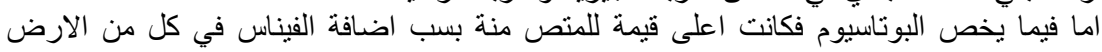
الجيرية و التربة الغبر جيرية (الرملية).

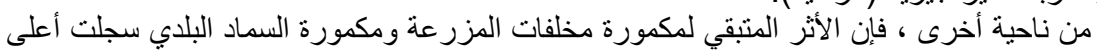

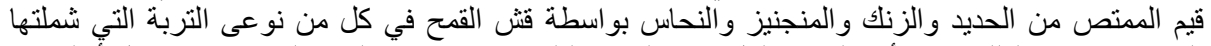

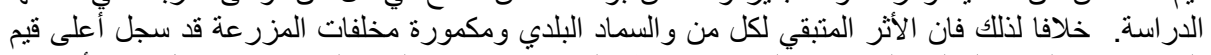

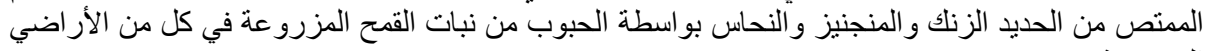

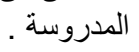

كلية الزراعه - جامعة المنصوره

قام بتحكيم البحث

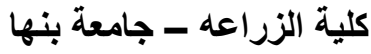

